DOI: $10.19195 / 0137-1134.117 .10$

\author{
KAROLINA STOPKA \\ ORCID: 0000-0003-1199-9350 \\ Uniwersytet Wrocławski
}

\title{
PRAWO DO ZASIŁKU MACIERZYŃSKIEGO PO USTANIU UBEZPIECZENIA CHOROBOWEGO - WYBRANE ZAGADNIENIA
}

\begin{abstract}
Abstrakt: W opracowaniu przeanalizowano regulację prawną zasiłku macierzyńskiego po ustaniu ubezpieczenia chorobowego, zawartą w art. 30 ustawy o świadczeniach pieniężnych z ubezpieczenia społecznego w razie choroby i macierzyństwa. Analizy tej dokonano pod kątem podstaw uzasadniających ochronę ubezpieczeniową po ustaniu ubezpieczenia, rodzaju zdarzeń objętych ochroną, a także okoliczności warunkujących z niej skorzystanie. Przy ocenie okoliczności warunkujących prawo do zasiłku odwołano się do przepisów kodeksu pracy normujących uprawnienia pracowników związane z rodzicielstwem oraz z niezgodnym z prawem rozwiązaniem umowy o pracę przez pracodawcę. W opracowaniu odniesiono się także do konstrukcji zasiłku i sformułowano postulaty de lege ferenda.
\end{abstract}

Słowa kluczowe: ubezpieczenia społeczne, prawo pracy, zasiłek macierzyński, ochrona macierzyństwa i rodzicielstwa

\section{UWAGI WPROWADZAJĄCE}

Zasiłek macierzyński jest świadczeniem realizowanym w ramach społecznego ubezpieczenia chorobowego. Zgodnie z obowiązującymi przepisami ubezpieczeniu temu podlega się obowiązkowo lub dobrowolnie. Obowiązkowo ubezpieczeniu chorobowemu podlegają pracownicy oraz członkowie rolniczych spółdzielni produkcyjnych i spółdzielni kółek rolniczych ${ }^{1}$, dobrowolnie zaś, objęte obowiązkowo ubezpieczeniami emerytalnym i rentowymi, osoby wykonujące pracę nakładczą,

1 Zob. art. 11 ust. 1 ustawy z dnia 13 października 1998 roku o systemie ubezpieczeń społecznych (tekst jedn. Dz.U. z 2017 r. poz. 1778 ze zm.), dalej: ustawa systemowa. Przepis ten do osób podlegających obowiązkowo ubezpieczeniu chorobowemu zalicza również osoby odbywające służbę zastępczą. Aktualnie nie ma jednak obowiązku odbywania służby zastępczej, co oznacza, że przymusowo wspólnotę ryzyka w ubezpieczeniu chorobowym tworzą tylko pracownicy i członkowie wyżej wymienionych spółdzielni. Zob. A. Przybyłowicz, Solidarność w ubezpieczeniu chorobowym - wybrane zagadnienia, mps s. 5 . 
osoby wykonujące pracę na podstawie umowy agencyjnej lub umowy zlecenia albo innej umowy o świadczenie usług, do której zgodnie z kodeksem cywilnym stosuje się przepisy dotyczące zlecenia, oraz osoby z nimi współpracujące, osoby prowadzące pozarolniczą działalność oraz osoby z nimi współpracujące, doktoranci otrzymujący stypendium doktoranckie, osoby wykonujące odpłatnie pracę na podstawie skierowania do pracy, w czasie odbywania kary pozbawienia wolności lub tymczasowego aresztowania oraz duchowni ${ }^{2}$.

Ogólną właściwością ubezpieczeniowej ochrony jest to, że zdarzenia uzasadniające ochronę muszą zaistnieć w czasie trwania ubezpieczenia. W tym sensie świadczenia z ubezpieczenia społecznego chronią skutki zdarzeń losowych powstałych w czasie trwania ubezpieczenia społecznego. W wypadku ubezpieczenia chorobowego skutki te obejmują przejściową utratę zdolności lub możliwości wykonywania pracy w czasie trwania zatrudnienia lub prowadzenia innej działalności i zdobywania poprzez ich wykonywanie środków utrzymania. Konsekwentnie celem świadczeń z ubezpieczenia chorobowego jest częściowa kompensata szkody wynikającej z utraty prawa do wynagrodzenia lub przychodu ${ }^{3}$. Od tej ogólnej zasady przepisy ustawy z 25 czerwca 1990 roku o świadczeniach pieniężnych z ubezpieczenia społecznego w razie choroby i macierzyństwa ${ }^{4}$ przewidują wyjątki. Należy do nich między innymi regulacja art. 30 dotycząca zasiłku macierzyńskiego — świadczenia przysługującego ubezpieczonemu, któremu urodziło się dziecko lub który przysposobił dziecko, lub przyjął dziecko na wychowanie w ramach rodziny zastępczej, lub sprawuje nad nim osobistą opiekę ${ }^{5}$.

Zgodnie $\mathrm{z}$ art. 30 ustawy zasiłek macierzyński przysługuje również $\mathrm{w}$ razie urodzenia dziecka po ustaniu ubezpieczenia chorobowego, jeżeli ubezpieczenie to ustało w okresie ciąży wskutek ogłoszenia upadłości lub likwidacji pracodawcy lub z naruszeniem przepisów prawa, stwierdzonym prawomocnym orzeczeniem sądu (ust. 1). Zasiłek macierzyński po ustaniu ubezpieczenia chorobowego przysługuje ponadto ubezpieczonej będącej pracownicą zatrudnioną na podstawie umowy o pracę na czas określony, z którą umowa o pracę na podstawie art. 177 $\S 3$ kodeksu pracy została przedłużona do dnia porodu (ust. 4).

Ponieważ prawo do zasiłku macierzyńskiego po ustaniu tytułu ubezpieczenia ma charakter wyjątkowy, z punktu widzenia ogólnych właściwości ochrony ubezpieczeniowej, w tym ubezpieczenia chorobowego, powinno mieć szczególne uzasadnienie.

Na wstępie wypada zauważyć, że prawo do zasiłku macierzyńskiego po ustaniu ubezpieczenia nie ma bezpośredniego umocowania w prawie międzynarodowym. Pierwowzoru jego polskiej regulacji nie można odnaleźć zwłaszcza w konwencji nr 102 MOP dotyczącej minimalnych norm zabezpieczenia społecz-

\footnotetext{
2 Zob. art. 11 ust. 2 ustawy systemowej.

3 Zob. J. Jończyk, Prawo zabezpieczenia społecznego, Kraków 2001, s. 17, 204.

4 Tekst jedn. Dz.U. z 2017 r. poz. 1368 ze zm. (dalej: ustawa zasiłkowa).

5 Zob. art. 29 ustawy zasiłkowej.
} 
nego, stanowiącej aktualnie najważniejszy akt prawny i podstawowy instrument międzynarodowy w dziedzinie zabezpieczenia społecznego ${ }^{6}$, oraz w konwencjach MOP dotyczących ochrony macierzyństwa ${ }^{7}$.

Aksjologicznego i normatywnego oparcia regulacji prawnej tego świadczenia poszukiwać zatem wypada $\mathrm{w}$ dobrach (wartościach) ogólnie chronionych - na poziomie krajowym w przepisach Konstytucji, podkreślających wartość społeczną macierzyństwa ${ }^{8}$ (stosunku istniejącego między dzieckiem i jego matką od początku ciąży ${ }^{9}$ ) oraz rodzicielstwa (stosunku między rodzicem - matką, ojcem a dzieckiem ${ }^{10}$ ), to jest $w$ art. 18 ustawy zasadniczej, który stanowi, że macierzyństwo i rodzicielstwo znajdują się pod ochroną i opieką Rzeczypospolitej Polskiej, oraz $\mathrm{w}$ art. 71 ustawy zasadniczej, nakazującym państwu uwzględnianie dobra rodziny w polityce społecznej i gospodarczej (ust. 1) oraz przyznającym matce przed i po urodzeniu dziecka prawo do szczególnej pomocy władz publicznych, a także w przepisach art. 72 ustawy zasadniczej, statuujących zasadę ochrony praw dziecka, w tym zasadę priorytetu roli rodziców w sprawowaniu opieki nad dzieckiem (ust. 2) ${ }^{11}$, tym bardziej że ochrona dziecka jest elementem ochrony macierzyństwa i rodzicielstwa, a ostatecznym beneficjentem zasiłku macierzyńskiego nie jest ubezpieczony (były ubezpieczony), lecz dziecko ${ }^{12}$, które z przyczyn obiektywnych wymaga szczególnej pieczy. W aktualnym stanie prawnym zasiłek macierzyński, przysługując bezpośrednio ubezpieczonemu, służy nie tylko i nie przede wszystkim zaspokojeniu jego indywidualnych potrzeb, lecz głównie potrzebo jego dziecka (rodziny) i z uwagi na obowiązki względem niego (rodziny)

${ }^{6}$ K. Ślebzak, Prawo do zabezpieczenia społecznego w Konstytucji RP. Zagadnienia podstawowe, Warszawa 2016, s. 48-49. Wprawdzie Polska nie przyjęła zobowiązań w odniesieniu do części VIII konwencji nr 102 pod tytułem Świadczenia macierzyńskie, jednak wywiera ona duży wpływ na ratyfikowane przez Polskę akty prawa międzynarodowego, statuujące prawo do zabezpieczenia społecznego i treść wiążących Polskę aktów prawa unijnego. Szerzej zob. K. Ślebzak, op. cit., s. 43, 50-51.

7 Tekst jedn. konwencji MOP nr 103 z 4 czerwca 1952 roku dotyczącej ochrony macierzyństwa (Dz.U. z 1976 r. Nr 16, poz. 99) oraz nieratyfikowanej przez Polskę konwencji MOP nr 183 z 15 czerwca 2000 roku dotyczącej ochrony macierzyństwa, rewidującej konwencję nr 103.

8 Szerzej na temat społecznej funkcji macierzyństwa zob. np. M. Soboń, Ekonomiczne przyczyny ochrony macierzyństwa, [w:] Funkcja ochronna prawa pracy a wyzwania współczesności, red. M. Bosak, Warszawa 2014, s. 103, 104.

9 W. Borysiak, [w:] Konstytucja RP, t. 1. Komentarz do art. 1-86, red. M. Safjan, L. Bosek, Warszawa 2016, s. 490. W doktrynie prawa rodzinnego uznaje się, że macierzyństwo powinno być odnoszone przede wszystkim do więzi łączącej kobietę ciężarną z jej nienarodzonym jeszcze dzieckiem, zob. J. Ignatowicz, M. Nazar, Prawo rodzinne, Warszawa 2005, s. 48.

10 W. Borysiak, op. cit., s. 492.

11 Ibidem, s. 1650. Zob. też H. Pławucka, Zasilki z ubezpieczenia społecznego na rzecz rodziny, [w:] Ubezpieczenie społeczne rodziny, red. J. Jończyk, Wrocław 1985, s. 86-87.

${ }_{12}$ T. Lasocki, Zasada równości ptci $w$ dostępie do zasiłku macierzyńskiego, „Praca i Zabezpieczenie Społeczne" (dalej: PiZS) 2011, nr 6, s. 9. 
ubezpieczony został do niego uprawniony ${ }^{13}$. Zasiłek ten jest zatem indywidualnym świadczeniem ubezpieczonego, uwarunkowanym jednak przede wszystkim potrzebami dziecka (ochroną jego zdrowia i prawidłowego rozwoju). Na taką ocenę wpływa brak wymogu posiadania przez ubezpieczonego odpowiedniego okresu ubezpieczenia oraz natura okoliczności, które determinują prawo do tego świadczenia (na przykład urodzenie dziecka lub przyjęcie dziecka do wspólnoty domowej, sprawowanie osobistej opieki nad dzieckiem), a nadto przyznanie możliwości korzystania z niego różnym członkom rodziny dziecka.

Poza tym regulacja zasiłku macierzyńskiego po ustaniu ubezpieczenia ma również swoje oparcie w zasadach finansowania ubezpieczenia chorobowego i rodzaju okoliczności pozwalających na przedłużenie ochrony ubezpieczeniowej. $Z$ tej perspektywy regulację tę można uznać za konsekwencję finansowania świadczeń z ubezpieczenia chorobowego przez ubezpieczonych ${ }^{14}$ oraz konsekwencję szczególnych okoliczności utraty tytułu do ubezpieczenia chorobowego - niezależnych czy też niezawinionych przez ubezpieczonego.

\section{PRZEDMIOTOWY I PODMIOTOWY ASPEKT PRAWA DO ZASIŁKU MACIERZYŃSKIEGO PO USTANIU UBEZPIECZENIA CHOROBOWEGO}

$\mathrm{Z}$ regulacji art. 30 ust. 1 i 4 ustawy zasiłkowej wynika, że prawo do zasiłku macierzyńskiego po ustaniu ubezpieczenia chorobowego jest prawem przedmiotowo i podmiotowo ograniczonym.

Ustawa łączy prawo do zasiłku macierzyńskiego po ustaniu ubezpieczenia chorobowego wyłącznie z macierzyństwem biologicznym. Zasadniczą przesłanką wypłaty zasiłku jest bowiem urodzenie dziecka po ustaniu ubezpieczenia. Ograniczenie to nie jest, jak się wydaje, uwarunkowane odmienną oceną społecznej wartości macierzyństwa biologicznego i macierzyństwa prawno-społecznego, jeśli patrzeć na nią nie tylko przez pryzmat przyrostu naturalnego, lecz także znaczenia rodziny w procesie wychowania dzieci i młodzieży ${ }^{15}$. Podstaw tego ograniczenia upatrywać należy raczej w przepisach Konstytucji, które gwarantują szczególną

13 Zob. H. Pławucka, op. cit., s. 87; D. Dzienisiuk, Prawo pracy a prawo a prawo ubezpieczeń społecznych, Warszawa 2016, s. 330-331.

14 Zob. art. 16 ust. 2, 4 pkt 1 i ust. 11 ustawy systemowej. Wskazana zasada nie dotyczy osób współpracujących z osobami prowadzącymi pozarolniczą działalność lub z osobami fizycznymi, o których mowa w art. 18 ust. 1 ustawy z dnia 6 marca 2018 roku - Prawo przedsiębiorców. W wypadku tych osób składki na ubezpieczenia społeczne, w tym ubezpieczenie chorobowe, finansuje w całości z własnych środków osoba prowadząca pozarolniczą działalność lub osoba fizyczna, o której mowa w art. 18 ust. 1 ustawy — Prawo przedsiębiorców (art. 16 ust. 5a ustawy systemowej).

15 Zob. np. Ł. Pisarczyk, Uprawnienia rodziców adopcyjnych w prawie pracy, [w:] Uprawnienia pracowników zwiazane z rodzicielstwem $w$ świetle przepisów prawa pracy i ubezpieczeń społecznych, red. J. Czerniak-Swędzioł, Warszawa 2016, s. 105. 
pomoc władz publicznych matkom biologicznym („,matce przed i po urodzeniu dziecka" - art. 71 ust. 2) oraz w tendencji kształtowania regulacji prawnej zasiłku macierzyńskiego przez pryzmat przepisów prawa pracy dotyczących szczególnej ochrony zatrudnienia, która w interesującym nas zakresie, pierwotnie, a aktualnie w najszerszym stopniu, odnosi się do macierzyństwa biologicznego ${ }^{16}$. Przepisy kodeksu pracy pracownikom dążącym do macierzyństwa (rodzicielstwa) prawno-społecznego gwarantują trwałość zatrudnienia wyłącznie w okresie korzystania $\mathrm{z}$ uprawnienia do urlopu na warunkach urlopu macierzyńskiego ${ }^{17}$.

Związek zasiłku macierzyńskiego po ustaniu tytułu ubezpieczenia z macierzyństwem biologicznym wskazuje, że z perspektywy społecznej zasiłek ten jest między innymi narzędziem polityki pronatalnej państwa ${ }^{18}$.

Przedmiotowe ograniczenie prawa do zasiłku macierzyńskiego po ustaniu ubezpieczenia łączy się również z zamkniętym katalogiem sytuacji, w których urodzenie dziecka daje prawo do tego świadczenia. Z perspektywy rozwoju ustawodawstwa ubezpieczenia chorobowego zakres tych sytuacji można uznać za jednolity. Abstrahując od szczegółowych różnic, należy zauważyć, że obejmował on i nadal obejmuje trzy typy stanów faktycznych: 1 . zakończenie bytu prawnego pracodawcy, 2. bezprawne ustanie ubezpieczenia (zatrudnienia) oraz 3. upływ terminu przedłużenia czasu trwania terminowej umowy o pracę ${ }^{19}$. Od strony przedmiotowej zasiłek macierzyński po ustaniu ubezpieczenia nawiązuje zatem do szczególnej ochrony stabilności zatrudnienia, stanowiącej jeden z fundamentów ochrony macierzyństwa ${ }^{20}$ i rodzicielstwa. Spośród wymienionych sytuacji w praktyce szczególne znaczenie ma ustanie ubezpieczenia społecznego z naruszeniem przepisów prawa. Dlatego też dalsze wywody skoncentrowane będą, co do zasady, na prawie do zasiłku macierzyńskiego po ustaniu ubezpieczenia chorobowego z tego właśnie powodu.

Choć ustawa nie stanowi tego wprost, prawo do zasiłku macierzyńskiego po ustaniu ubezpieczenia chorobowego jest prawem podmiotowo ograniczonym. Stany faktyczne kształtujące prawo do zasiłku macierzyńskiego po ustaniu ubezpieczenia chorobowego określone są z użyciem terminologii właściwej materii prawa pracy i nawiązują do szczególnej ochrony trwałości stosunku pracy pracownicy

16 Zob. np. przepisy ustawy z 2 lipca 1924 roku w przedmiocie pracy młodocianych i kobiet (Dz.U. z 1924 r. Nr 65, poz. 636).

17 Szerzej na temat urlopu na warunkach urlopu macierzyńskiego zob. K. Stopka, Urlop na warunkach urlopu macierzyńskiego, PiZS 2016, nr 9, 23-31.

18 Por. U. Jackowiak, Kilka uwag o społecznej roli zasitków, [w:] Problemy zatrudnienia we wspótczesnym ustroju pracy. Księga Jubileuszowa na 55-lecie pracy naukowej i dydaktycznej Profesora Włodzimierza Piotrowskiego, red. Z. Niedbała, M. Skąpski, Poznań 2009, s. 78.

19 Por. np. art. 30 ust. 1 pkt 3 i art. 33 ust. 1 pkt 2 ustawy z dnia 17 grudnia 1974 roku o świadczeniach pieniężnych z ubezpieczenia społecznego w razie choroby i macierzyństwa (tekst jedn. Dz.U. z 1974 r. Nr 47, poz. 1983; Nr 30, poz. 143 ze zm.). Zob. też H. Pławucka, op. cit., s. 95.

20 A. Sobczyk, Prawo pracy w świetle Konstytucji RP, t. 2. Wybrane problemy i instytucje prawa pracy a konstytucyjne prawa i wolności człowieka, Warszawa 2013, s. $193 \mathrm{n}$. 
w ciąży, o której mowa w art. 177 k.p. Wyjątkowy charakter w tym zakresie ma pkt 2 art. 30 ust. 1 ustawy, który łączy ustanie ubezpieczenia chorobowego ogólnie z naruszeniem przepisów prawa, stwierdzonym prawomocnym orzeczeniem sądu.

Neutralne zakresowo brzmienie przepisu art. 30 ust. 1 pkt 2 ustawy legło u podstaw wyrażonego w literaturze przedmiotu poglądu, że przepis ten zapewnia ochronę również innym kategoriom ubezpieczonych ${ }^{21}$. Wskazanie ubezpieczonych niebędących pracownikami podlegającymi społecznemu ubezpieczeniu chorobowemu, wobec których przepis ten może znaleźć zastosowanie, wymaga analizy przepisów normujących stosunki prawne stanowiące w ich przypadku tytuł ubezpieczenia.

$Z$ regulacji prawnych normujących inne niż stosunek pracy stosunki prawne, mające praktyczne znaczenie w tworzeniu wspólnoty w ramach ubezpieczenia chorobowego, wynika, że art. 30 ust. 1 pkt 2 ustawy zasiłkowej stwarza gwarancję ochrony ubezpieczeniowej ubezpieczonym niebędącym pracownikami objętymi z mocy przepisów szczególnych uprawnieniami pracowniczymi, to jest osobom wykonującym pracę nakładczą ${ }^{22}$ oraz członkom rolniczych spółdzielni produkcyjnych i spółdzielni kółek rolniczych, jeśli przyjąć, że przysługujące im prawo do świadczeń związanych z okresem ciąży, urodzeniem i wychowaniem małego dziecka na zasadach określonych w przepisach prawa pracy obejmuje również ochronę trwałości zatrudnienia wynikającego ze stosunku członkostwa w rolniczej spółdzielni produkcyjnej (trwałości stosunku spółdzielczego, możliwości wykonywania pracy na rzecz spółdzielni) z tytułu prawa do pracy przysługującego członkom tej spółdzielni ${ }^{23}$. Prawo do zasiłku macierzyńskiego po ustaniu ubezpieczenia chorobowego $\mathrm{z}$ naruszeniem przepisów prawa nie dotyczy natomiast osób prowadzących działalność gospodarczą oraz zleceniobiorców, z wyjątkiem wykonawców umowy agencyjnej.

Przepisy kodeksu cywilnego, normujące zatrudnienie cywilnoprawne na podstawie umowy zlecenia, umowy agencyjnej czy też umowy o świadczenie usług, oparte na założeniu równorzędności stron, nie przewidują dla jego wykonawców szczególnej gwarancji zatrudnienia ze względu na sytuację osobistą, na przykład stan ciąży ${ }^{24}$. Podmiot zatrudniający ma prawo do wypowiedzenia umowy zlecenia, umowy o świadczenie usług w każdym momencie jej trwania, bez względu na okoliczności, a także bez zaistnienia ku temu ważnej przyczyny czy też zachowania jakiegokolwiek okresu wypowiedzenia ${ }^{25}$. Bez znaczenia dla oceny sytuacji prawnej wykonawców zatrudnienia cywilnego na podstawie tych umów w sferze prawa

21 T. Lasocki, op. cit., s. 12.

22 Zob. § 7 rozporządzenia Rady Ministrów z dnia 31 grudnia 1975 roku w sprawie uprawnień pracowniczych osób wykonujących pracę nakładczą (Dz.U. z 1976 r. Nr 3, poz. 19).

23 Por. art. 11 i art. 13 pkt 3 ustawy systemowej w zw. z art. 155 i art. $161 \S 1$ ustawy 16 września 1982 roku — Prawo spółdzielcze (tekst jedn. Dz.U. z 2018 r. poz. 1285 ze zm.).

24 Zob. art. 746 i 750 k.c.

25 K. Kopaczyńska-Pieczniak, Komentarz do art. 746 k.c., [w:] Kodeks cywilny. Komentarz, t. 3. Zobowiązania - część szczególna, red. A. Kidyba, LEX 2014. 
do zasiłku macierzyńskiego po ustaniu ubezpieczenia chorobowego pozostaje przy tym wprowadzenie przez strony do umowy postanowień chroniących wykonawcę przed jej rozwiązaniem, skoro ustawa wymaga stwierdzenia ustania ubezpieczenia chorobowego z naruszeniem przepisów prawa. Przed rozwiązaniem umowy chroniony jest tylko wykonawca umowy agencyjnej niezależnie od tego, czy umowa ta została zawarta na czas określony, czy nieoznaczony. Ustawodawca nie zezwala bowiem na wypowiedzenie terminowej umowy agencyjnej, w wypadku zaś umowy zawartej na czas nieoznaczony nakłada na strony umowy obowiązek zachowania minimalnych terminów wypowiedzenia ${ }^{26}$. W wypadku umowy agencyjnej ograniczenie swobody umów w zakresie jej wypowiadania ma niewątpliwie inną aksjologię aniżeli wartości leżące u podstaw ochrony trwałości stosunku pracy.

Wobec tego nie jest nadużyciem stwierdzenie, że w aktualnym stanie prawnym analizowany zasiłek jest świadczeniem pomyślanym głównie na rzecz ubezpieczonego pracownika (faza gwarancyjna) czy też inaczej byłego ubezpieczonego pracownika (faza realizacji) ${ }^{27}$. Takie ukształtowanie prawa do zasiłku macierzyńskiego po ustaniu ubezpieczenia może budzić zastrzeżenia z punktu widzenia ogólnych wartości leżących u jego podstaw i wspólnoty ryzyka. Opieka i ochrona macierzyństwa oraz rodzicielstwa, a także dobro dziecka jako wartości konstytucyjne mają charakter powszechny, są niezależne od statusu pracowniczego matki czy rodzica dziecka. $Z$ istotą zaś wspólnoty ryzyka kłóci się finansowanie uprawnienia przysługującego jednej kategorii ubezpieczonych (pracowników) przez wszystkich członków tworzących wspólnotę ryzyka w ramach ubezpieczenia chorobowego ${ }^{28}$, choć ten stan rzeczy niewątpliwie łagodzi to, że pracownicy są najliczniejszą grupą wśród wszystkich ubezpieczonych tworzących wspólnotę ryzyka w ramach ubezpieczenia chorobowego. Są też głównymi odbiorcami tego świadczenia ${ }^{29}$.

\section{PRAWO DO ZASIŁKU MACIERZYŃSKIEGO PO USTANIU UBEZPIECZENIA CHOROBOWEGO Z NARUSZENIEM PRZEPISÓW PRAWA}

Ustanie ubezpieczenia $\mathrm{z}$ naruszeniem przepisów prawa ubezpieczony pracownik (były ubezpieczony pracownik) może wykazać wyłącznie przez powódz-

26 Zob. art. $764^{1}$ k.c.

27 Podobnie D. Dzienisiuk, op. cit., s. 328.

28 Por. A. Przybyłowicz, op. cit., mps, s. 17. Zdaniem autora prawo do zasiłku macierzyńskiego po ustaniu ubezpieczenia budzi zastrzeżenia z punktu widzenia wspólnoty ryzyka i ubezpieczeń społecznych oraz powinno zostać zastąpione świadczeniem finansowanym w ramach wspólnoty narodowej.

29 Zob. J. Korpas, M. Wojtkowska, J. Sarbiński, Informacja o wypłacie zasitków z Funduszu Ubezpieczeń Społecznych, „Ubezpieczenia Społeczne. Teoria i Praktyka” 2017, nr 2, s. 187 n.; Rocznik Statystyczny Ubezpieczeń Społecznych 2012-2014, Warszawa 2016, s. 86. 
two przewidziane w kodeksie pracy o uznanie wypowiedzenia za bezpodstawne, o przywrócenie do pracy lub o odszkodowanie ${ }^{30}$. Jeżeli pracownik nie złoży takiego powództwa, ustanie ubezpieczenia społecznego w następstwie rozwiązania umowy o pracę korzysta $\mathrm{z}$ domniemania zgodności z prawem.

Mając na uwadze brzmienie art. 30 ust. 1 pkt 2 ustawy zasiłkowej, prima facie bezdyskusyjne wydaje się, że w każdym wypadku urodzenie dziecka po ustaniu ubezpieczenia z powodu naruszenia przepisów prawa stwierdzonego prawomocnym orzeczeniem sądu będzie obciążać instytucję ubezpieczeniową (wspólnotę ubezpieczonych) wypłatą zasiłku. Ustawa nie wprowadza bowiem w tym zakresie żadnych dodatkowych warunków. W praktyce jednak wniosek ten nie jest tak oczywisty. Uwaga ta dotyczy sytuacji, gdy stwierdzenie naruszenia przepisów następuje w orzeczeniu o przywróceniu pracownicy do pracy na poprzednich warunkach pracy i płacy, zasądzającym na jej rzecz od pracodawcy (pod warunkiem podjęcia pracy) wynagrodzenie za cały czas pozostawania bez pracy, w tym również de facto za okres urlopu macierzyńskiego i urlopu rodzicielskiego, z którego pracownica mogłaby skorzystać w związku z urodzeniem dziecka, gdyby nie doszło do rozwiązania stosunku pracy ${ }^{31}$. Pojawia się wówczas pytanie, czy zasądzenie tego wynagrodzenia jest okolicznością wyłączającą prawo do zasiłku macierzyńskiego na podstawie art. 12 ust. 1 ustawy zasiłkowej, stosowanego odpowiednio do zasiłku macierzyńskiego z mocy art. 31 ust. 5 tej ustawy.

Zgodnie z art. 12 ust. 1 ustawy zasiłkowej zasiłek chorobowy nie przysługuje za okresy niezdolności do pracy, w których ubezpieczony na podstawie przepisów o wynagradzaniu zachowuje prawo do wynagrodzenia. Okresy te wlicza się do okresu zasiłkowego. Przepis ten odnosi się do regulacji, których celem jest zapewnienie ubezpieczonemu dochodu, będącego podstawą utrzymania i zaspokajania jego potrzeb życiowych, w okresie niewykonywania pracy. Użyte w tym przepisie wyrażenie „zachowanie prawa do wynagrodzenia” oznacza pozostanie uprawnionym do wynagrodzenia mimo nieświadczenia pracy, a więc zaistnienia okoliczności wyłączających prawo do wynagrodzenia. Przepis art. 12 nawiązuje zatem do przypadków tak zwanej ochrony pierwotnej, w prawie pracy będącej wyrazem ryzyka socjalnego pracodawcy i statuującej odstępstwo od fundamentalnej zasady prawa pracy, że wynagrodzenie przysługuje za pracę wykonaną ${ }^{32}$, obciążającej pracodawcę kosztami polityki społecznej ${ }^{33}$, w tym prowadzącej do redukcji zakresu i kosztu ubezpieczenia chorobowego ${ }^{34}$, a więc będącej przykładem realizacji przez państwo polityki społecznej (polityki zabezpieczenia

30 Wyrok SN z dnia 25 lutego 2009 roku, II PK 164/08, OSNP 2010, nr 19-20, nr 227.

31 Zob. wyrok SN z dnia 3 października 2018 roku, sygn. akt II UK 283/17, OSNP 2019, nr 5, poz. 60 .

32 J. Jończyk, op. cit., s. 199.

33 Zob. J. Czerniak-Swędzioł, Rola pracodawcy w realizowaniu uprawnień pracowników zwiazanych z rodzicielstwem, „Przegląd Prawa i Administracji” 2018, nr 113, s. 23-41.

34 J. Jończyk, op. cit., s. 206. 
społecznego) poprzez solidarność indywidualną (obciążenia pracodawcy) ${ }^{35}$. Przepis ten odnosi się zatem do tych przypadków, w których wedle przepisów prawa pracy (kodeksu pracy lub pragmatyk służbowych) pracownik zachowuje prawo do wynagrodzenia, mimo że nie świadczy pracy z powodów, z którymi ustawa zasiłkowa łączy prawo do zasiłku chorobowego oraz innych świadczeń, do których przepis ten stosuje się z mocy stosownego odesłania. Zachowanie prawa do wynagrodzenia uzasadnia nieprzyznanie świadczenia z ubezpieczenia społecznego, które z założenia w takich sytuacjach ma zastąpić wynagrodzenie za pracę. Tym samym odpowiednie stosowanie przepisu art. 12 ustawy zasiłkowej do zasiłku macierzyńskiego powinno oznaczać, że ubezpieczonemu pracownikowi, który w okresie urlopu macierzyńskiego, urlopu rodzicielskiego, urlopu ojcowskiego czy też urlopu na warunkach urlopu macierzyńskiego zachowuje prawo do wynagrodzenia, zasiłek macierzyński nie przysługuje za czas tej nieobecności w pracy, chociaż jej okres podlega wliczeniu do okresu zasiłkowego, odpowiadającego długości okresu pobierania zasiłku macierzyńskiego, co byłoby logicznie możliwe pod warunkiem, że okres, za który ubezpieczony pracownik zachowuje prawo do wynagrodzenia, byłby krótszy niż okres zasiłkowy zasiłku macierzyńskiego ${ }^{36}$.

Zachowanie prawa do wynagrodzenia w okresach przejściowej utraty zdolności lub możliwości świadczenia pracy na rzecz pracodawcy przewiduje art. 92 k.p., statuujący tak zwane prawo do wynagrodzenia chorobowego (gwarancyjnego). Przepis ten nie obejmuje jednak niemożności wykonywania pracy przez pracownicę ze względu na stan ciąży, w szczególności przygotowania się do porodu, porodu i połogu oraz opieki nad nowo narodzonym dzieckiem. Przepisy kodeksu pracy wprost obejmują ochroną wskazane stany wyłącznie w postaci uprawnienia do urlopu macierzyńskiego, a w odniesieniu do opieki nad nowo narodzonym dzieckiem również w postaci uprawnienia do urlopu rodzicielskiego i urlopu ojcowskiego, stanowiąc jednocześnie, że za okres tych urlopów pracownikowi przysługuje zasiłek macierzyński z ustawy zasiłkowej (art. 184 k.p.). Ochrona tych stanów przybiera zatem postać świadczenia o charakterze niepieniężnym. W tym kontekście w doktrynie wskazuje się, że ,pracodawca nie ponosi ryzyka socjalnego związanego z macierzyństwem na takich zasadach jak przy urlopie chorobowym oraz że jest to rozwiązanie słuszne" 37 . Rozwiązanie to uwzględnia postanowienia konwencji MOP dotyczących ochrony macierzyństwa, które przewidują tworzenie obowiązkowego ubezpieczenia socjalnego lub funduszy publicznych zapewniających świadczenia pieniężne za okres urlopu macierzyńskiego oraz wyłączenie indywidualnej odpo-

35 Zob. A. Sobczyk, op. cit., s. 179.

36 Zob. B. Wagner, Zasiłki i wynagrodzenia za czas nieobecności w pracy, „Przegląd Ubezpieczeń Społecznych i Gospodarczych" 2000, nr 5, s. 6.

37 Tak A. Sobczyk, Komentarz do art. 184 k.p., [w:] Kodeks pracy. Komentarz, red. A. Sobczyk, Warszawa 2017, s. 753; J. Czerniak-Swędzioł, op. cit., s. 32. 
wiedzialności pracodawcy za koszty bezpośrednie takiego świadczenia na rzecz zatrudnianej przez niego kobiety ${ }^{38}$.

Jak już nadmieniono, w praktyce stosowania art. 12 ustawy zasiłkowej próbowano objąć jego dyspozycją również przepis art. 47 k.p., statuujący prawo do wynagrodzenia za czas pozostawania bez pracy pracownicy, z którą umowę o pracę na czas nieokreślony rozwiązano w okresie ciąży. Próby te budzą zastrzeżenia ze względów systemowych i funkcjonalnych. Można je uznać za konsekwencję błędnego stosowania przepisu art. 47 k.p. w tym przypadku czy też trudności w jego zastosowaniu, mające po części uzasadnienie w regulacji prawnej uprawnień rodzicielskich, za których okres przysługuje zasiłek macierzyński.

Generalnie w nauce i judykaturze charakter wynagrodzenia za czas pozostawania bez pracy nie jest ujmowany jednolicie. Część przedstawicieli doktryny przyjmuje, że wynagrodzenie to, jako uregulowane poza działem trzecim kodeksu pracy pod tytułem Wynagrodzenie za pracę $i$ inne świadczenia ${ }^{39}$, nie jest wynagrodzeniem za pracę. Inni wskazują, że jest ono na mocy ustawy szczególną odmianą wynagrodzenia za pracę, do którego pracownik ma prawo, ponieważ nie wykonał pracy z winy pracodawcy. Dlatego też użyte w art. 47 k.p. określenie „wynagrodzenie za czas pozostawania bez pracy" należy rozumieć jako wynagrodzenie za czas niemożności świadczenia pracy u pracodawcy, który dokonał wypowiedzenia niezgodnego z prawem ${ }^{40}$. Większość autorów podkreśla jednocześnie, że jest to świadczenie spełniające przede wszystkim funkcję kompensacyjną ${ }^{41}$ czy też świadczenie o charakterze odszkodowawczym, które należy odróżnić od odszkodowania w ścisłym tego słowa znaczeniu ${ }^{42}$. Niekiedy uznaje się je wprost za odszkodowanie za szkodę poniesioną przez pracownika w następstwie utraty wynagrodzenia za pracę wskutek niezgodnego z prawem rozwiązania przez pracodawcę stosunku pracy ${ }^{43}$. Dla rozważań podjętych w opracowaniu istotny jest pogląd, zgodnie z którym określenie ,wynagrodzenie za cały czas pozostawania bez pracy" jest równoznaczne z przyznaniem prawa do pełnego wynagrodzenia za taki okres, w którym pracownik miałby prawo do wynagrodzenia, gdyby pozostawał w rozwiązanym stosunku pracy ${ }^{44}$. Chodzi przy tym tylko o taki okres, w którym pracownik mógł wykonywać pracę, to znaczy był gotów do podjęcia jej

38 Zob. art. 4 ust. 4 i 8 konwencji MOP nr 103 oraz art. 6 ust. 8 konwencji MOP nr 183. Szerzej zob. Ł. Pisarczyk, Ryzyko pracodawcy, Warszawa 2008, s. 261.

39 Tak np. Z. Góral, [w:] Kodeks pracy. Komentarz, red. K.W. Baran, Warszawa 2018, s. 393; T.M. Romer, Komentarz do art. 47 k.p., [w:] eadem, Prawo pracy. Komentarz, Warszawa 2012.

40 Tak L. Florek, [w:] Kodeks pracy. Komentarz, red. L. Florek, Warszawa 2017, s. 347. Zob. też M. Piankowski, [w:] Kodeks pracy. Komentarz, red. U. Jackowiak, Gdynia 2004, s. 241-243.

41 Zob. L. Florek, op. cit., s. 347; Z. Góral, op. cit., s. 393-394.

42 Zob. R. Sadlik, Wynagrodzenie za czas pozostawania bez pracy, „Monitor Prawa Pracy” 2013, nr 1, s. 21.

43 Tak np. A.M. Świątkowski, Kodeks pracy. Komentarz, Warszawa 2016, s. 325.

44 Wyrok SN z dnia 9 grudnia 2003 roku, I PK 81/03, OSNP 2004/21/370; wyrok SN z dnia 12 września 2012 roku, II PK 45/12, Lex nr 1243023. 
świadczenia, a nie świadczył, gdyż został jej pozbawiony wyłącznie ze względu na bezprawną odmowę dopuszczenia go do pracy ${ }^{45}$. Stanowisko to było punktem wyjścia wykazania zasadności odliczenia od okresu, za który pracownik powinien otrzymać wynagrodzenie za czas pozostawania bez pracy, okresu pobierania zasiłku chorobowego, świadczenia rehabilitacyjnego oraz renty z tytułu niezdolności do pracy wraz z dodatkiem pielęgnacyjnym z tytułu niezdolności do samodzielnej egzystencji, skoro nie był on w tym czasie gotowy do świadczenia pracy ${ }^{46}$.

Opierając się na przyjętym w nauce i judykaturze rozumieniu określenia „wynagrodzenie za czas pozostawania bez pracy”, należałoby przyjąć, że stosowanie przepisu art. 47 k.p. w wypadku pracownicy, z którą rozwiązano stosunek pracy w okresie ciąży, powinno uwzględniać regulację uprawnień rodzicielskich, zwłaszcza urlopu macierzyńskiego.

Urlop macierzyński jest jedynym urlopem w kodeksie pracy, który rozpoczyna się z mocy prawa. Sam fakt urodzenia dziecka przez kobietę będącą pracownicą powoduje jego rozpoczęcie. Pracownica nie musi składać wniosku o skorzystanie z niego, a pracodawca nie może jej dopuścić do pracy ${ }^{47}$. Oznacza to, że z dniem porodu pracownica nie może przystąpić do wykonywania pracy i w związku z tym przestaje być uprawniona do wynagrodzenia za pracę. Tym samym, gdyby pracownica, z którą rozwiązano umowę o pracę z naruszeniem prawa, pozostawała w stosunku pracy, nie zachowałaby prawa do wynagrodzenia, począwszy od dnia porodu. Okres korzystania z urlopu macierzyńskiego powinien być zatem odliczony od okresu pozostawania bez pracy, za który pracownicy przysługuje wynagrodzenie za czas pozostawania bez pracy. Sęk w tym, że przepisy normujące urlop macierzyński utrudniają wskazanie okresu, o który należałoby pomniejszyć okres wynagrodzenia za czas pozostawania bez pracy. Pracownica, która ma obowiązek skorzystania z urlopu macierzyńskiego, nie ma już obowiązku wykorzystania go w pełnym wymiarze, określonym w art. $180 \S 1$ k.p. Biorąc pod uwagę zasady korzystania z urlopu macierzyńskiego, wynagrodzenie za okres pozostawania bez pracy nie powinno obejmować przynajmniej 8 tygodni po porodzie (czyli okresu tak zwanej przerwy połogowej), ewentualnie 14 tygodni po porodzie, czyli minimalnego okresu, po którym pracownica, zdrowa i zdolna do samodzielnej egzystencji, opiekująca się nowo narodzonym dzieckiem może powrócić do pracy u dotychczasowego pracodawcy ${ }^{48}$. Pomniejszenie okresu wynagrodzenia za czas pozostawania bez pracy o okres pozostałych uprawnień rodzicielskich związanych z opieką nad nowo narodzonym czy też małym dzieckiem (urlop ojcowski, urlop rodzicielski) wyklucza natomiast ich fakultatywny charakter. W ich wypadku utrata prawa do wynagrodzenia następuje tylko wówczas, gdy pracownik wystąpi o ich udzielenie.

\footnotetext{
45 Wyrok SN z dnia 17 listopada 1998 roku, I PKN 443/98, OSNAPiUS 2000, nr 1, poz. 12.

46 Wyrok SN z dnia 19 kwietnia 2006 roku, I PK 158/05, OSN 2007, nr 7-8, poz. 99.

47 M. Mędrala, Uprawnienia rodzicielskie niepracowników na gruncie prawa pracy i ubezpieczeń społecznych, [w:] Uprawnienia pracowników..., s. 71.

48 Por. art. $180 \S 4-13$ k.p. oraz art. $180^{1}$ k.p. do art. 182 k.p.
} 
Wracając do zasadniczego wątku tej części rozważań, opowiadam się przeciw socjalnemu charakterowi wynagrodzenia za czas pozostawania bez pracy. Za takim stanowiskiem przemawia brak formalnoprawnych związków wynagrodzenia za czas pozostawania bez pracy z zasiłkiem macierzyńskim, sugerujących, że jest to wynagrodzenie przysługujące zamiast zasiłku macierzyńskiego. Tym samym uznaję, że nie jest to wynagrodzenie za pracę, w tym o charakterze gwarancyjnym, lecz inne świadczenie związane ze stosunkiem pracy, którego celem jest zagwarantowanie realizacji przez pracodawcę obowiązku ochronnego kobiet w ciąży poprzez zwiększenie dotkliwości finansowej w razie jego naruszenia. Ochrona istotnych wartości społecznych — macierzyństwa — nie jest ratio tego świadczenia, lecz tylko okolicznością wpływającą na jego wysokość. Socjalny charakter wynagrodzenia za czas pozostawania bez pracy podważa również fakt, że nie jest to świadczenie płatne periodycznie, lecz świadczenie jednorazowe, należne pracownikowi po przywróceniu do pracy ${ }^{49}$. Za przyjętym stanowiskiem przemawia nadto akcesoryjny charakter wynagrodzenia za czas pozostawania bez pracy wobec roszczenia o przywrócenie do pracy i fakt, że osoba dochodząca przywrócenia do pracy może w ogóle nie żądać wynagrodzenia za czas pozostawania bez pracy ${ }^{50}$.

Wyrażony pogląd znajduje wreszcie oparcie w wykładni historycznej. Pod rządami poprzednio obowiązującej ustawy zasiłkowej, to jest ustawy z 17 grudnia 1975 roku o świadczeniach pieniężnych z ubezpieczenia społecznego w razie choroby i macierzyństwa ${ }^{51}$, zasiłek macierzyński przysługiwał w razie urodzenia dziecka po ustaniu zatrudnienia, jeżeli rozwiązanie umowy o pracę w okresie ciąży nastąpiło z naruszeniem przepisów prawa, a pracownica otrzymała $\mathrm{z}$ tego tytułu odszkodowanie (art. 33 ust. 1 pkt 2 w zw. z art. 30 ust. 1 pkt 3 lit. b. tej ustawy). Pod rządami tej ustawy przywrócenie do pracy pracownicy, z którą rozwiązano stosunek pracy, i przyznanie wynagrodzenia za czas pozostawania bez pracy wyłączało zatem możliwość przyznania jej zasiłku macierzyńskiego po ustaniu zatrudnienia. Uwarunkowanie w obowiązującej ustawie — zarówno w brzmieniu pierwotnym, jak i obecnym — prawa do zasiłku ustaniem ubezpieczenia z naruszeniem przepisów prawa, stwierdzonym prawomocnym orzeczeniem sądu, wskazuje zatem, że wolą ustawodawcy jest, by prawo do zasiłku przysługiwało bez względu na rodzaj świadczeń uzyskanych przez ubezpieczonego z tytułu niezgodnego z prawem ustania stosunku prawnego, będącego tytułem ubezpieczenia. Aktualną regulację należy uznać za słuszną. Jak zauważa B. Wagner, uprawnienia objęte treścią stosunku pracy nie powinny mieć bezpośredniego wpływu na uprawnienia wynikające ze stosunku ubezpieczenia chorobowego. Stosunki te, choć są z sobą powiązane czasowo i jednostronnie — podmiotowo, mają charak-

49 R. Sadlik, op. cit., s. 21.

50 Postanowienie SN z dnia 18 stycznia 2012 roku, II PZ 38/11, Lex nr 1130381.

51 Dz.U. z 1974 r. Nr 47, poz. 280 ze zm. 
ter odrębny. Świadczenia z ubezpieczenia chorobowego odwzajemniają składkę uiszczaną przez ubezpieczonego na rzecz Funduszu Ubezpieczeń Społecznych ${ }^{52}$.

Reasumując, w aktualnym stanie prawnym wynagrodzenie za czas pozostawania bez pracy jest instrumentem ochronnym, a nie pomocowym. Ma zapobiegać nierespektowaniu przez pracodawców przepisów zapewniających, że macierzyństwo, rodzicielstwo nie będzie przyczyną utraty pracy.

\section{UWAGI KOŃCOWE}

Generalnie nie ulega wątpliwości, że zasiłek macierzyński po ustaniu ubezpieczenia zabezpiecza sytuację ekonomiczną matki nowo narodzonego dziecka, zagrożoną „niezawinioną” utratą zatrudnienia. Normatywna funkcja tego zasiłku jest jednak trudna do jednoznacznego określenia. Niewątpliwie ze względu na to, że prawo do tego świadczenia powstaje po ustaniu ubezpieczenia, świadczenie to nie odnosi się do przeszkód w zakresie wykonywania pracy i zdobywania poprzez jej wykonywanie środków utrzymania.

Jeśli wziąć pod uwagę wynikający z przepisów kodeksu pracy czy też prawa międzynarodowego zakaz podjęcia pracy przez kobietę $\mathrm{w}$ okresie połogu ${ }^{53}$, to cel zasiłku można byłoby konsekwentnie sprowadzić do zabezpieczenia bytu materialnego ubezpieczonej na wypadek przejściowej przeszkody w podjęciu wynagradzanego zatrudnienia w związku z urodzeniem dziecka ${ }^{54}$. Jeśli mieć zaś na względzie okres uprawniający do tego świadczenia, znacznie przekraczający okres połogu, oraz okoliczność, że przepisy prawa krajowego nie przewidują instrumentów wyłączających możliwość wykonywania i podejmowania pracy zarobkowej w okresie połogu (ograniczają tylko możliwość świadczenia pracy na rzecz dotychczasowego pracodawcy, i to tylko w ramach wiążącego strony stosunku pracy), to za jego normatywny cel można byłoby uznać po prostu zabezpieczenie bytu materialnego ubezpieczonej w związku z urodzeniem dziecka. W tym ostatnim wypadku zasiłek kompensowałby wydatki związane z powiększeniem się rodziny. Powyższe wzmacnia trafność wyrażonego w doktrynie poglądu o niejednorodnej naturze (kon-

52 B. Wagner, Zasada równego traktowania w ubezpieczeniu chorobowym, [w:] Ubezpieczenia chorobowe, red. B. Wagner, A. Malaka, Iwonicz-Zdrój 2010, s. 29.

$53 \mathrm{~Np}$. art. 3 pkt a) konwencji nr 3 MOP dotyczącej zatrudnienia kobiet przed i po porodzie (Dz.U. z 1976 r. Nr 15, poz. 99) stanowi, że w każdym przedsiębiorstwie państwowym czy prywatnym, przemysłowym czy handlowym lub w jakichkolwiek ich oddziałach, z wyjątkiem przedsiębiorstwa, w którym pracują wyłącznie członkowie tej samej rodziny, kobiecie nie zezwala się na podjęcie pracy przez sześć tygodni bezpośrednio po porodzie.

54 Zob. H. Pławucka, op. cit., s. 95. 
strukcji) zasiłku macierzyńskiego pod kątem chronionego ryzyka oraz społecznego i ubezpieczeniowego celu, który ma realizować to świadczenie ${ }^{55}$.

Rozważając zasadność utrzymania zasiłku macierzyńskiego jako jednego świadczenia lub zastąpienia go innym świadczeniem, którego nazwa byłaby bardziej adekwatna do stanów faktycznych, uzasadniających obecnie prawo do niego, de lege ferenda ustawodawca powinien rozważyć również zakres podmiotowy prawa do tego świadczenia po ustaniu ubezpieczenia i dostosować go do kręgu podmiotów ubezpieczenia chorobowego w zgodzie z zasadą równości. Wyznacznikiem zakresu przyszłej regulacji prawnej w tej kwestii powinny być, z jednej strony, wartości ogólne, za których przejaw można uznać konstrukcję zasiłku po ustaniu ubezpieczenia (opieka i ochrona macierzyństwa i rodzicielstwa oraz ochrona dobra dziecka wymagającego opieki rodzica,) z drugiej zaś zapewnienie środków utrzymania matce, rodzicowi, którzy nie z własnej winy utracili źródła przychodu. Jak już wskazano, w aktualnym stanie prawnym zasiłek macierzyński po ustaniu ubezpieczenia jest w głównej mierze uprawnieniem ubezpieczonej pracownicy i wyrazem szczególnej ochrony trwałości stosunku pracy pracownicy w ciąży. Tymczasem opieka i ochrona macierzyństwa oraz rodzicielstwa jako wartości konstytucyjne mają charakter powszechny. Są niezależne od statusu pracowniczego matki czy rodzica. Przykładowo zaś upadłość nie jest tylko kategorią właściwą pracodawcy, która jako jedyna jest wyraźnie ujęta $\mathrm{w}$ dyspozycji art. 30 ust. 1 pkt 1 ustawy zasiłkowej. W sferze zatrudnienia cywilnoprawnego upadłość może dotknąć obie strony umowy agencyjnej oraz zatrudniającego w ramach umowy zlecenia lub umowy o świadczenie usług ${ }^{56}$. Dzień jej ogłoszenia skutkuje wygaśnięciem umowy oraz ustaniem ubezpieczenia społecznego ${ }^{57}$. Poza tym upadłość czy likwidacja pracodawcy lub bezprawne rozwiązanie stosunku pracy pracownika może pozbawiać go uprawnienia do urlopu ojcowskiego, pozwalającego na integrację rodziny, otoczenie opieką matki i dziecka lub załatwienie niezbędnych spraw urzędowych ${ }^{58} \mathrm{czy}$ też możliwości dzielenia się obowiązkami opiekuńczo-wychowawczymi z matką dziecka — w obu przypadkach — w warunkach dających poczucie bezpieczeństwa finansowego.

55 Zob. np. A. Wypych-Żywicka, Świadczenia z ubezpieczenia chorobowego - wybrane zagadnienia, [w:] Ubezpieczenia chorobowe..., s. 57-58 i 65; L. Mitrus, Prawo do zasitku macierzyńskiego w świetle nowelizacji kodeksu pracy i ustawy zasitkowej (analiza zmian i postulaty de lege ferenda), [w:] Uprawnienia pracowników..., s. 100; R. Babińska-Górecka, Ewolucja funkcji zasiłku macierzyńskiego (uwagi na tle ostatnich zmian przestanek nabycia prawa do zasiłku macierzyńskiego dla ubezpieczonego ojca dziecka, PiZS 2015, nr 11, s. 9-15.

56 Zob. art. 102 i 103 ustawy z dnia 28 lutego 2003 roku — Prawo upadłościowe (tekst jedn. Dz.U. z 2017 r. poz. 2344 ze zm.).

57 Zob. art. 14 ust. 2 pkt 3 w zw. z art. 13 pkt 2 ustawy systemowej.

58 Por. Ł. Pisarczyk, Ryzyko pracodawcy..., s. 265. 


\title{
MATERNITY ALLOWANCE AFTER THE EXPIRY OF ILLNESS INSURANCE — SELECTED ISSUES
}

\begin{abstract}
Summary
The study analyzed the regulation of maternity allowance after the expiry of illness insurance contained in Article 30 of the Act on Cash Benefits from Social Insurance in Case of Illness and Motherhood. This analysis was carried out in terms of the grounds justifying insurance coverage after the expiry of the insurance, the type of events covered by the protection as well as the circumstances conditioning the use of it. When assessing the circumstances determining the right to the allowance, the provisions of the Labour Code determining the rights of employees in relation to parenthood and in the case of an unlawful termination of the employment contract by the employer were referred to. The study also referred to the construction of the allowance and formulated de lege ferenda postulates.
\end{abstract}

Keywords: social insurances, labour law, maternity allowance, parent- and motherhood protection

\section{BIBLIOGRAFIA}

Babińska-Górecka R., Ewolucja funkcji zasiłku macierzyńskiego (uwagi na tle ostatnich zmian przestanek nabycia prawa do zasitku macierzyńskiego dla ubezpieczonego ojca dziecka, PiZS 2015, nr 11.

Czerniak-Swędzioł J., Rola pracodawcy w realizowaniu uprawnień pracowników zwiazanych z rodzicielstwem, „Przegląd Prawa i Administracji” 2018, nr 113.

Dzienisiuk D., Prawo pracy a prawo a prawo ubezpieczeń społecznych, Warszawa 2016.

Ignatowicz J., Nazar M., Prawo rodzinne, Warszawa 2005.

Jackowiak U., Kilka uwag o społecznej roli zasiłków, [w:] Problemy zatrudnienia we wspótczesnym ustroju pracy. Ksiega Jubileuszowa na 55-lecie pracy naukowej i dydaktycznej Profesora Włodzimierza Piotrowskiego, red. Z. Niedbała, M. Skąpski, Poznań 2009.

Jończyk J., Prawo zabezpieczenia społecznego, Kraków 2001.

Kodeks pracy. Komentarz, red. K.W. Baran, Warszawa 2018.

Kodeks pracy. Komentarz, red. L. Florek, Warszawa 2017.

Kodeks pracy. Komentarz, red. U. Jackowiak, Gdynia 2004.

Konstytucja RP, t. 1. Komentarz do art. 1-86, red. M. Safjan, L. Bosek, Warszawa 2016.

Kopaczyńska-Pieczniak K., Komentarz do art. 746 k.c., [w:] Kodeks cywilny. Komentarz, t. 3. Zobowiazzania - część szczególna, red. A. Kidyba, LEX 2014

Korpas J., Wojtkowska M., Sarbiński J., Informacja o wypłacie zasiłków z Funduszu Ubezpieczeń Społecznych, „Ubezpieczenia Społeczne. Teoria i Praktyka” 2017, nr 2.

Mędrala M., Uprawnienia rodzicielskie niepracowników na gruncie prawa pracy i ubezpieczeń społecznych, [w:] Uprawnienia pracowników związane z rodzicielstwem w świetle przepisów prawa pracy i ubezpieczeń społecznych, red. J. Czerniak-Swędzioł, Warszawa 2016.

Mitrus L., Prawo do zasitku macierzyńskiego w świetle nowelizacji kodeksu pracy $i$ ustawy zasitkowej (analiza zmian i postulaty de lege ferenda), [w:] Uprawnienia pracowników zwiazane z rodzicielstwem w świetle przepisów prawa pracy i ubezpieczeń społecznych, red. J. Czerniak-Swędzioł, Warszawa 2016.

Pisarczyk Ł., Ryzyko pracodawcy, Warszawa 2008.

Pisarczyk Ł., Uprawnienia rodziców adopcyjnych w prawie pracy, [w:] Uprawnienia pracowników zwiazane z rodzicielstwem $w$ świetle przepisów prawa pracy $i$ ubezpieczeń spolecznych, red. J. Czerniak-Swędzioł, Warszawa 2016. 
Pławucka H., Zasitki z ubezpieczenia społecznego na rzecz rodziny, [w:] Ubezpieczenie społeczne rodziny, red. J. Jończyk, Wrocław 1985.

Przybyłowicz A., Solidarność w ubezpieczeniu chorobowym - wybrane zagadnienia, mps.

Rocznik Statystyczny Ubezpieczeń Społecznych 2012-2014, Warszawa 2016.

Romer T.M., Prawo pracy. Komentarz, Warszawa 2012.

Sadlik R., Wynagrodzenie za czas pozostawania bez pracy, „Monitor Prawa Pracy” 2013, nr 1.

Sobczyk A., Prawo pracy w świetle Konstytucji RP, t. 2. Wybrane problemy i instytucje prawa pracy a konstytucyjne prawa $i$ wolności człowieka, Warszawa 2013.

Soboń M., Ekonomiczne przyczyny ochrony macierzyństwa, [w:] Funkcja ochronna prawa pracy a wyzwania wspótczesności, red. M. Bosak, Warszawa 2014.

Ślebzak K., Prawo do zabezpieczenia społecznego w Konstytucji RP. Zagadnienia podstawowe, Warszawa 2016.

Stopka K., Urlop na warunkach urlopu macierzyńskiego, PIZS 2016, nr 9.

Świątkowski A.M., Kodeks pracy. Komentarz, Warszawa 2016.

Wypych-Żywicka A., Świadczenia z ubezpieczenia chorobowego - wybrane zagadnienia, [w:] Ubezpieczenia chorobowe, red. B. Wagner, A. Malaka, Iwonicz-Zdrój 2010.

Wagner B., Zasada równego traktowania w ubezpieczeniu chorobowym, [w:] Ubezpieczenia chorobowe, red. B. Wagner, A. Malaka, Iwonicz-Zdrój 2010.

Wagner B., Zasitki i wynagrodzenia za czas nieobecności w pracy, „Przegląd Ubezpieczeń Społecznych i Gospodarczych" 2000, nr 5. 